\title{
IMPLEMENTASI SISTEM INFORMASI DESA SEBAGAI MEDIA PEMBANGUNAN BISNIS PERTANIAN BERKELANJUTAN DI MASA PANDEMI COVID-19 DI KABUPATEN KONAWE SELATAN SULAWESI TENGGARA
}

Iskandar Zainuddin Rela ${ }^{1}$, Musadar Mapasomba ${ }^{1}$, Salahuddin ${ }^{1}$, Yoenita Jayadisastra ${ }^{1}$, Darsilan Dima ${ }^{1}$, Bakri Yusuf 2 , Dian Agustina ${ }^{3}$, Inda Paratu ${ }^{4}$, Nurul Fitriani ${ }^{4}$, Nia Tirani ${ }^{4}$

1 Jurusan Penyuluhan Pertanian Fakultas Pertanian UHO

2 Jurusan Ilmu Kesejahteraan Sosial Fakultas Sosial dan Politik UHO

3 Jurusan Ilmu Peternakan Fakultas Peternakan UHO

${ }^{4}$ Mahasiswa Jurusan Penyuluhan Pertanian Fakultas Pertanian UHO

Koresponden: (iskandar faperta@uho.ac.id)

\section{RINGKASAN}

Teknologi telah mengalami perkembangan pesat, Sistem Informasi Desa (SID) di Indonesia masih tertinggal jauh dibandingkan dengan kota. Memperkenalkan (SID) sebagai media informasi untuk meningkatkan kapasitas dan kesejahteraan masyarakat. Kegiatan pengabdian masyarakat tentang implementasi sistem informasi desa sebagai media pembangunan bisnis pertanian berkelanjutan di masa Pandemi Covid-19 diharapkan menjadi sumber informasi dan media memberikan informasi yang bermanfaat, serta dapat memberikan manfaat ekonomi. Pelatihan tentang penggunaan SID yang melibatkan 10 orang Apparat Desa mitra telah memberikan peningkatan pengetahuan dan keterampilan bagi aparat desa di Desa Amoito dan Desa Sindangkasih. Agar SID ini dapat diaplikasikan secara terus menerus maka diharapkan dilakukan komunikasi dan pendampingan kerjasama Penguruan Tinggi dan Pemerintah setempat.

\section{Kata kunci : Sistem informasi desa, teknologi komunikasi, kesejahteraan masyarakat desa, kapasitas masyarakat}

\section{A. Analisis Situasi}

Saat ini, teknologi informasi dan komunikasi sudah menjadi aspek penting dalam kehidupan manusia. Walaupun teknologi telah mengalami perkembangan pesat, sistem informasi desa di Indonesia nyatanya masih tertinggal jauh dibandingkan dengan kota. Masyarakat yang menempati wilayah urban menikmati berbagai fasilitas dan akses tanpa mengalami kesulitan. Sementara daerah-daerah yang relatif terpencil harus mampu memanfaatkan teknologi yang sebenarnya sudah ketinggalan zaman. Memperkenalkan sistem informasi modern di desa salah satu faktor utama yang membuat sebagian besar desa di Indonesia masih terbelakang adalah keengganan orang-orang untuk 
mengembangkannya. Sehingga banyak dari warga yang tinggal di desa memilih mengadu nasib di kota besar dengan harapan dapat lebih beruntung. Padahal, ada satu cara yang sebenarnya dapat diterapkan tanpa harus meninggalkan desa, yakni memperkenalkan teknologi canggih dari kota yang mampu meningkatkan kesejahteraan. Pendekatan bisa dimulai dari hal yang sangat akrab dengan kehidupan sehari-hari: gadget. Walau belum semaju di kota, desa-desa di Tanah Air sudah menggunakan perangkat seperti komputer dan ponsel untuk memudahkan aktivitas masyarakatnya. Peluang tersebut semestinya dapat dimanfaatkan pihak-pihak yang berkecimpung dibidang teknologi untuk menciptakan aplikasi desa.

Mengapa aplikasi? Pasalnya, platform atau software tersebut sangat dekat dengan pemakaian komputer dan ponsel. Bahkan sekarang masyarakat tidak harus tergantung pada aplikasi buatan pengembang dari luar negeri, karena ada produkproduk lokal yang kualitasnya tak kalah bagus. Hal ini akan sangat cocok dengan warga desa yang rata-rata masih mempunyai keterbatasan dalam berbahasa Inggris. Tak hanya itu, dengan bantuan teknologi, masyarakat pedesaan dapat hidup makmur seperti orang perkotaan. Berbagai manfaat yang didapatkan dari aplikasi desa dapat meningkatkan sistem informasi desa merupakan manfaat yang akan dirasakan warga yang menetap di pedesaan. Jika biasanya mereka harus berkutat dengan buku dan alat hitung manual, kini mereka hanya perlu memasukkan data atau input dan mengoperasikan aplikasi untuk mengolah dan mendapatkannya dalam waktu singkat. Platform maupun software yang dirancang sedemikian rupa pun akan menampilkan akurasi tinggi, sehingga kesalahan perhitungan atau pendataan dapat dikurangi. Kemudian, perekonomian pedesaan pun dapat dibantu dengan pemakaian aplikasi.

Selama ini, petani maupun pemilik kebun kerap dirugikan karena mereka harus menjual hasil tani dan kebun dengan harga murah. Sementara saat diolah, hasil akhirnya dibanderol dengan harga tinggi. Namun, berkat aplikasi dan sistem informasi desa online, hasil tani dan kebun mereka tidak harus melewati rantai distribusi panjang lagi dan bisa langsung dijual dengan nilai sepantasnya kepada end user(konsumen). Bukan 
cuma urusan perkenomian, potensi pariwisata di desa yang jarang tersorot dapat dipromosikan melalui aplikasi. Dengan begitu, selain mengundang wisatawan dari berbagai tempat, promosi yang tepat pun akan menarik pemerintah setempat untuk membangun sarana dan pra-sarana yang mumpuni. Jika diterapkan dengan tepat, sektor pariwisata akan menciptakan lapangan kerja bagi warga sekitar. Aplikasi tepat untuk mengenalkan teknologi di desa yang berasal dari kontribusi pihak-pihak yang ahli di bidangnya untuk mensejahterakan warga desa belum lengkap tanpa instrumen yang tepat.

Dalam hal ini, SID (Sistem Informasi Desa) menghadirkan solusi yang menawarkan berbagai kebutuhan yang mampu mewujudkan manfaat-manfaat di atas. Di dalamnya terdapat sejumlah fitur dan layanan yang mampu mengolah informasi penting. SID juga sanggup membantu pembinaan sampai pengawasan dalam penyelenggaraan kegiatan pemerintah dan publik. Dengan berbagai kelebihan dan kelengkapan yang ada, aplikasi ini diharapkan mampu memenuhi kepentingan dan kebutuhan sistem informasi desa secara maksimal dan sesuai. Hal ini sesuai dengan pernyataan dari Utomo (2003) bahwa TIK harus digunakan untuk memberdayakan warga negara, meningkatkan kesejahteraan mereka, mengurangi kemiskinan dan menghilangkan kesenjangan digital. Badri (2016) mengatakan bahwa teknologi informasi dengan memanfaatkan TIK dapat meningkatkan pembangunan masyarakat di desa. Media komunikasi melaluo video training dan foto dapat meningkatkan pengetahuan dan keterampilan petani dalam adopsi teknologi (Iskandar, 2008)

Selama ini pemerintah sebenarnya mengakui bahwa data merupakan bahan pokok bagi perencanaan program pembangunan. Jika data lemah maka perencanaan tidak akan tepat. Lemahnya kualitas data, lemahnya keakuratan data dan penyediaan yang tidak tepat waktu menjadi permasalahan yang sering terjadi di jajaran institusi pemerintahan. Munculnya permasalahan data disebabkan oleh beberapa hal, antara lain pertama : mekanisme pengumpulan data sektoral di setiap Satuan Kerja Perangkat Daerah (SKPD) sering tidak terpusat dan tidak konsisten. Kedua, belum ada format baku 
dalam sistem pelaporan dari setiap SKPD yang sesuai dengan kebutuhan data. Jadi sering dijumpai data yang tumpang tindih (overlap) dan tidak sinkron. Ketiga, dari sisi non teknis penyebab munculnya permasalahan data juga dipicu oleh kesadaran dan komitmen SKPD dalam pengelolaan data masih kurang. Hal ini muncul karena langkah pembinaan dan pengembangan staf pemerintahan belum mencakup pada fokus pengolahan data dan informasi. Alasan klasik lainnya yang muncul adalah keterbatasan dana, baik untuk upaya pengembangan kapasitas staf maupun untuk pengembangan sistem informasi yang lebih baik. Keempat, belum adanya peraturan daerah yang mengatur tentang tata kelola data seperti peraturan daerah tentang statistik. Hal ini menyebabkan ketidakrapian sistem pengolahan data di jajaran institusi pemerintah kabupaten. Sejalan dengan upaya pemerintah pusat, kesadaran tentang pentingnya data pada saat yang sama juga telah berkembang di tingkat pemerintah daerah. Berbagai upaya dan inisiatif telah dilakukan untuk memperbaiki kinerja tata kelola pemerintahan daerah yang baik (Good Governance). Ketersediaan data yang dapat mewakili keadaan sebenarnya di lapangan disadari sebagai prasyarat penyediaan layanan dasar yang sesuai dengan kebutuhan masyarakat. Oleh karena itu, validitas dan akurasi data menjadi prinsip yang ingin terus ditingkatkan kualitasnya. Kebutuhan akan validitas data inilah yang mendasari lahirnya UU No. 06 Tahun 2014 tentang Desa, yang menyebutkan bahwa perencanaan pembangunan desa didasarkan pada data dan informasi yang akurat dan dapat dipertanggung jawabkan. Menyebarkan informasi publik adalah kewajiban badan publik.kewajiban badan publik untuk untuk menyebarkan informasi publik diamanatkan oleh UU No 14 Tahun 2008 Tentang Kebebasan Informasi Publik. Badan Publik harus membangun dan mengembangkan sistem informasi dan dokumentasi untuk mengelola Informasi Publik secara baik dan efisien sehingga dapat diakses dengan muda, diperkuat lagi di UU No 6 Tahun 2014 Pasal 82 (4) yang berbunyi pemerintah desa wajib menginformasikan perencanaan dan pelaksanaan Rencana Pembangunan Jangka Menengah Desa, Rencana Kerja Pemerintah Desa, dan Anggaran Pendapatan dan Belanja Desa kepada masyarakat Desa melalui layanan informasi 
kepada umum dan melaporkannya dalam Musyawarah Desa paling sedikit 1 (satu) tahun sekali. Ini sesuai dengan Tahir (2012) bahwa sinergitas Kepala Desa, pemerintah desa, pemuda dan masyarakat membentuk translansi jaringan yang begitu kuat dalam mendorong sebuah transformasi teknologi Cyber bagi masyarakat.

Desa yang akan menjadi mitra dari pembuatan SID ini adalah Desa Amoito Kecamatan Ranomeeto dan Desa Sindang Kasih Kecamatan Ranomeeto Barat Kabupaten Konawe Selatan Sulawesi Tenggara. Hal ini dikarenakan masyarakat desa belum memiliki informasi yang akurat mengenai sejarah terbentuknya desa, mayoritas mata pencaharian, jumlah penduduk, potensi-potensi yang dimiliki desa, kegiatan pemberdayaan yang dilakukan di desa, inovasi di bidang pertanian, maupun pasca panen hasil pertanian, bisnis pertanian, produksi pertanian, hingga trend bisnis saat ini. Ketidaktahuan itu disebabkan kurangnya informasi yang dimiliki oleh masyarakat. Sehingga tujuan dari pembangunan masyarakat pedesaan yang berorientasi pada keberdayaan masyarakat dalam memanfaatkan potensi sumberdaya yang ada di sekitar dalam bentuk inovasi-inovasi produk pertanian belum terwujud.

Selain itu, minimnya informasi dan edukasi pada masyarakat mengenai konsumsi pangan sehat dan bergizi yang berasal dari produk pertanian dan hewani yang dihasilkan oleh masyarakat setempat dengan tujuan untuk meningkatkan imunitas tubuh guna mencegah penularan Covid19. Sebagai bahan informasi, Covid19 adalah sejenis penyakit influenza yang menyerang imunitas tubuh manusia, terlebih bagi yang sudah memiliki penyakit bawaan (jantung, asma, diabetes, gagal ginjal, paru-paru). Untuk mencegah penyebarannya semakin meluas, maka anjuran dari pemerintah adalah jaga jarak aman, menggunakan masker, selalu mencuci tangan, dan mengkonsumsi pangan sehat yang bergizi. Hal ini sesuai dengan tujuan dari pengabdian ini yaitu melakukan sosialisasi pola konsumsi sehat dan bergizi pada masyarakat mitra. Hita et al. (2020) menyatakan bahwa status gizi memiliki hubungan yang signifikan dengan aktivitas fisik saat covid-19. Sehingga gizi seimbang adalah penting diterapkan dirumah untuk menjaga kesehatannya 
beserta keluarganya pada masa pandemi covid-19, sehingga selalu menerapkan pola hidup sehat, serta selalu konsumsi makanan yang bergizi dan seimbang (Akbar \& Aidha, 2020).

Pelatihan Sistem Informasi Desa (SID) sebagai media pembangunan bisnis pertanian dimaksudkan agar masyarakat desa mitra memperoleh informasi mengenai keadaan pembangunan pertanian di desanya masing-masing. Selain itu, hal tersebut juga dapat dijadikan ajang memperkenalkan desa kepada masyarakat luas. Adapun media yang akan dibuat adalah sebuah website desa. Objek dari pelatihan sistem informasi desa ini adalah perangkat desa mitra dan beberapa perwakilan dari masyarakat. Pengelola website desa diharapkan memiliki kreatifitas dalam menampilkan informasi tentang desa, tujuannya adalah menarik minat masyarakat untuk berkunjung ke website tersebut. Dari pelatihan tersebut, output yang diharapkan adalah masyarakat desa mitra melek teknologi dari Gadget masing-masing.

\section{B. Metode Pelaksanaan}

Program pengabdian ini dilaksanakan pada perangkat Desa Amoito Kecamatan Ranomeeto dan Desa Sindang Kasih Kecamatan Ranumeeto Barat Kabupaten Konawe Selatan Sulawesi Tenggara. Melalui kegiatan pengabdian ini, mitra akan memiliki pengetahuan akan pentingnya teknologi dalam menyebarluaskan informasi kepada masyarakat. Dalam hal ini, salah satu teknologi yang akan diberi pelatihan adalah membuat sebuah website yang berisi tentang informasi-informasi desa mitra, terdiri dari informasi mengenai sejarah terbentuknya desa, jumlah penduduk, mayoritas mata pencaharian penduduk, inovasi-inovasi pertanian, inovasi pengolahan pasca panen pertanian, pemasaran secara online, informasi mengenai pola pangan yang sehat dan bergizi dalam rangka meningkatkan imunitas tubuh dan mencegah penularan Covid19 dan informasi lainnya yang mendukung berkembangnya desa mitra menjadi desa melek teknologi. langkah-langkah pelaksanaan pengabdian terdiri dari persiapan, sosialisasi, desain web, pelatihan dan pendampingan dan evaluasi. 


\section{Hasil dan Pembahasan}

\section{Lokasi Kegiatan}

Program pengabdian telah dilaksanakan bagi perangkat Desa Amoito Kecamatan Ranomeeto dan Desa Sindang Kasih Kecamatan Ranumeeto Barat Kabupaten Konawe Selatan Sulawesi Tenggara. Melibatkan 9 orang partisipan. 5 orang dari Desa Amoito dan 4 orang dari Desa Sidangkasih.

\section{Pelaksanaan Kegiatan}

Pelaksanaan kegiatan pengabdian dilaksanakan sesuai dengan tahapan kegiatan. Semua tahapan kegiatan dilaksanakan secara baik dan mendapat dukungan yang positif dari masyarakat dan pemerintah setempat (kepala Desa). Pada kegiatan pelaksanaan pelatihan ini, dibuka langsung oleh kedua kepala Desa yaitu Bapak Usmin Mahseng sebagai kepala desa Amoito dan Bapak Akmad Supena. SIP sebagai kepala desa Sidang kasih. Persepsi pemerintah terhadap kegiatan ini sangat baik, pemerintah desa menilai bahwa kegiatan ini memberikan manfaat dalam mendapatkan informasi dan keterampilan terkait dengan sistem informasi desa (SID) yang dapat diakses secara on line. SID ini membantu desa dalam menyebarkan informasi, baik terkait potensi desa, informasi penduduk maupun informasi kesehatan terutama COVID-19. Hal ini sesuai dengan pernyataan Sofiyudin dan Nugroho (2017), bahwa edukasi ini memanfaatkan TIK berbasis Internet sebagai sumber informasi dalam menigkatkan pengetahuan masyarakat. Kegiatan ini juga telah didukung pendapat Pujilestari (2020) bahwa kegiatan belajar melalui internet merupakan metode yang temapat disaat pandemic. Berikut gambar proses kegiatan pelatihan SID. 


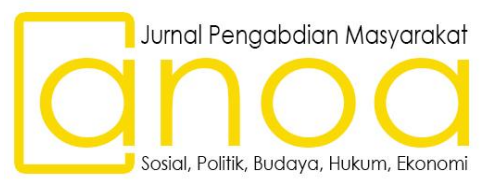

Vol. 2, No. 2, Hal. 190-201, Mei 2021

DOI: $10.52423 / A N O A . V 2 I 2.18632$
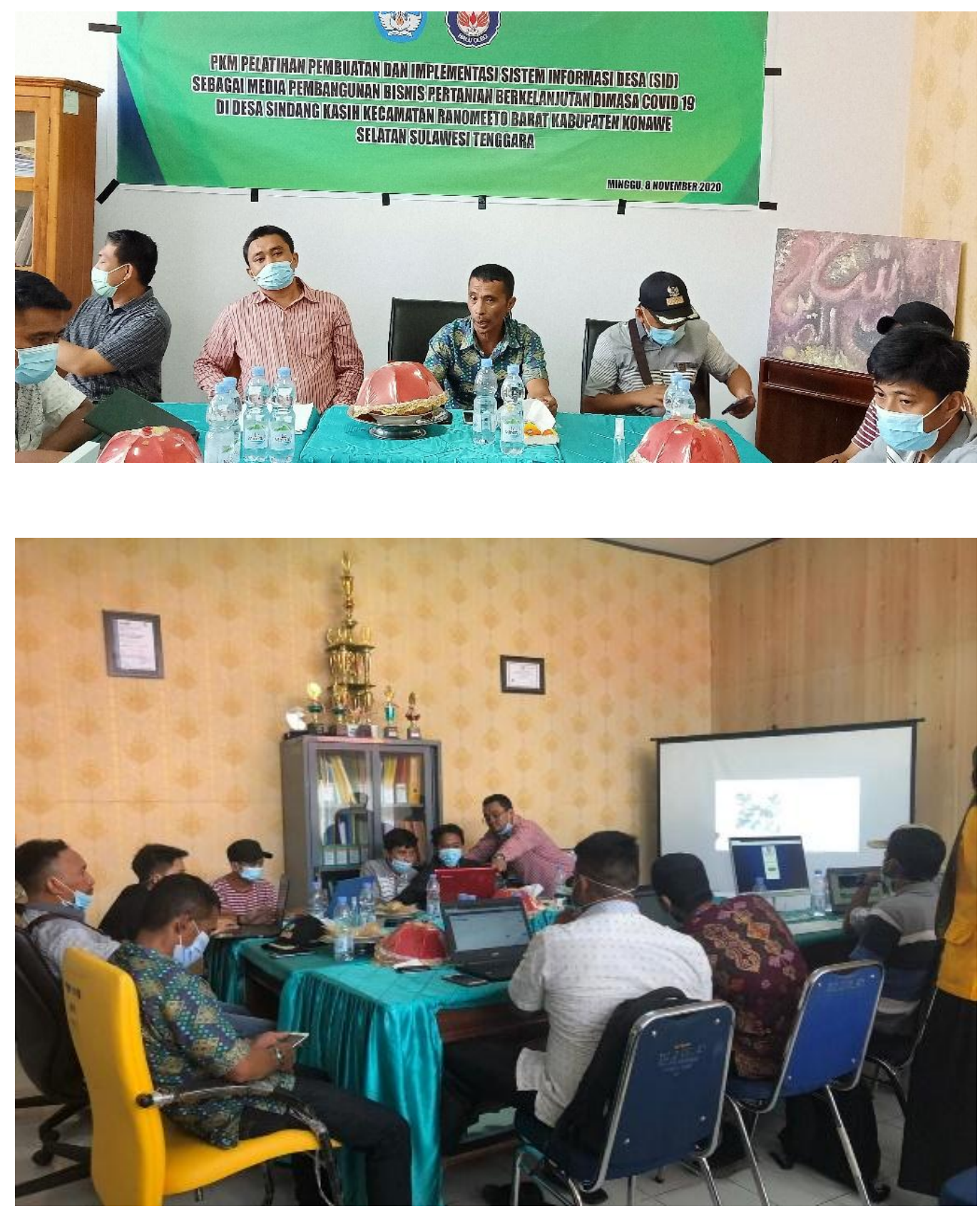

Gambar 1. Kegiatan Pelatihan SID 
Dia akhir kegiatan telah dilaksanakan evaluasi terhadap proses penilaian peningkatan pengetahuan dan keterampilan terhadap penggunaan aplikasi SID ini. Berikut hasil penilaian evaluasi Pre-test and Post-Test terhadap peserta.

\section{Tabel 3. Nilai Pre-test and Post-Test}

\begin{tabular}{cccc}
\hline Responden & Pre-test & Post-test & $\begin{array}{c}\text { Peningkatan } \\
\text { Pengetahuan }\end{array}$ \\
\hline 1 & 3 & 11 & 8 \\
2 & 3 & 9 & 6 \\
3 & 3 & 11 & 8 \\
4 & 2 & 11 & 9 \\
5 & 5 & 10 & 5 \\
6 & 1 & 10 & 9 \\
7 & 3 & 10 & 7 \\
8 & 4 & 10 & 6 \\
9 & 3 & 10 & 8 \\
10 & 3 & 11 & 73 \\
\hline Jumlah & 30 & 103 & 7.3 \\
\hline Rata-Rata & 3 & 10.3 & \\
\hline
\end{tabular}

Pada Tabel 3. menunjukkan bahwa ada peningkatan pengetahuan pada peserta pelatihan sesudah mengikuti pelathan SID. Nilai rata-rata pre-tes peserta atau sebelum diberikan materi pelatihan sebanyak 3,0 dan sesudah diberikan pelatihan, meningkat dengan total nilai 10,3 . Sedangkan nilai rata-rata peningkatan pengetahuan peserta adalah 7,3 (tren peninkatan nilai pada gambar 5). Hal ini bermaksud bahwa pelatihan tentang SID telah memberikan kontribusi peningkatan pengetahuan kepada peserta secara signifikan yang ditunjukkan adanya peningkatan pengetahuan, hal ini sependapat dengan Prawiranegara (2016) bahwa media internet telah memberikan peningkatan 
pengetahuan dan memahami inovasi bagi petani. Demikian juga Charina et al. (2016) melaporkan bahawa penerapan teknologi dan komunikasi melalui internet pada kelompok tani dapat memberikan informasi pasar tentang produk pertanian. Dengan demikian dapat disimpulkan bahwa pengunaan SID merupakan salah satu solusi sumber informasi yang dapat untuk meningkatkan pengetahuan dan keterampilan petani.

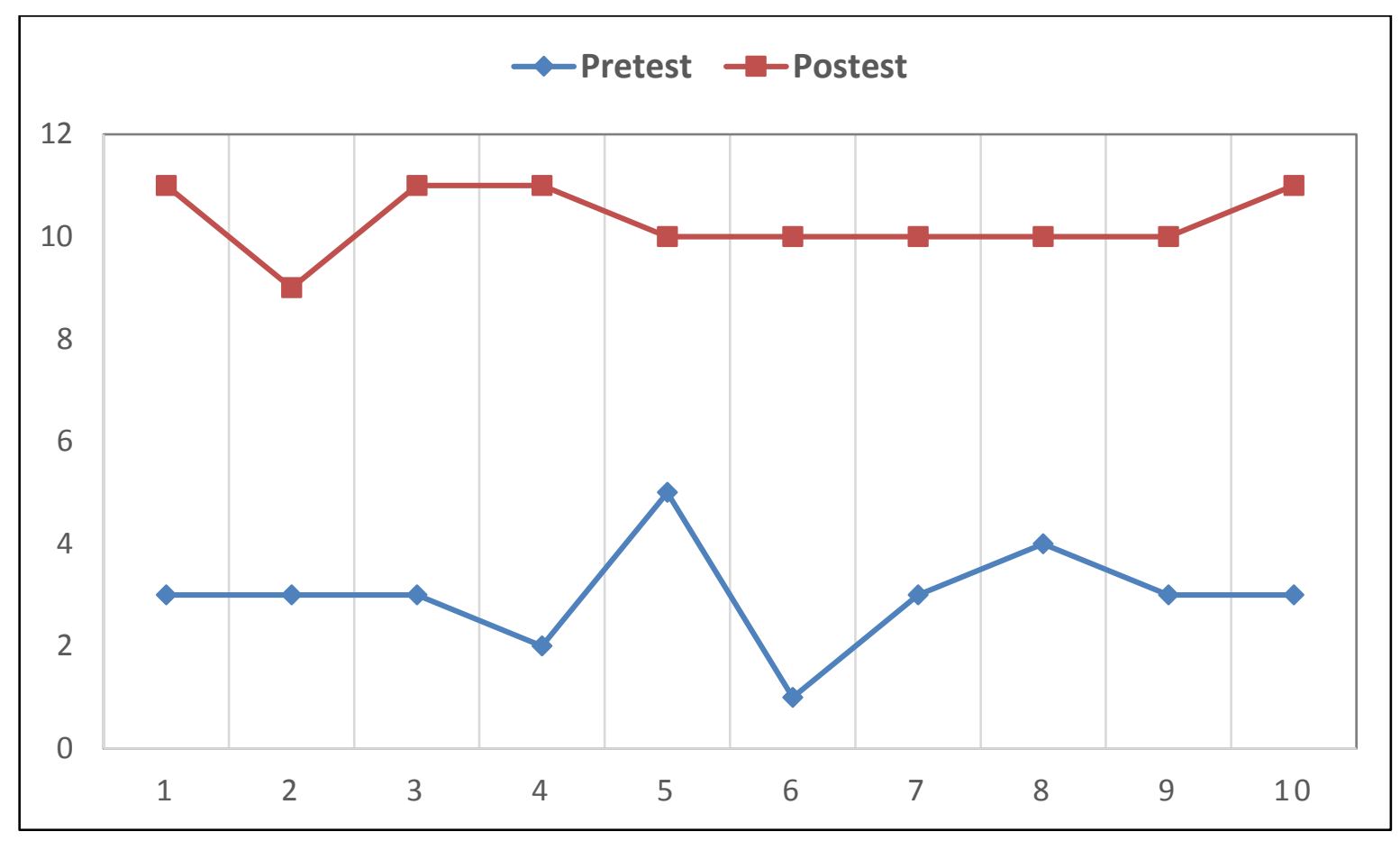

Gambar 5. Hasil pre-test dan post-test kegiatan pelatihan

\section{Kesimpulan}

Adapun kesimpulan yang diperoleh dari pengabdian ini adalah berikut :

1. Peningkatan pengetahuan peserta pengabdian mengenai konten digital, website, pemanfaatan media sosial sebagai tempat menggali informasi mengenai potensi desa mitra.

2. Masyarakat desa mitra dapat melakukan promosi pemasaran hasil-hasil pertanian, perkebunan, peternakan yang dimilikinya melalui website desa mitra yang telah 
tersedia.

3. Peningkatan pengetahuan masyarakat desa mitra mengenai bahan makanan yang dapat dihasilkan di desa masing-masing sebagai bentuk makanan bergizi untuk meningkatkan imunitas tubuh pada upaya pencegahan penyebaran covid-19.

4. Tim pengabdian akan tetap melakukan pendampingan dan pembimbingan pada desa mitra meskipun kegiatan pengabdian telah berakhir. Adapun kesepatakan yang ditetapkan sebelum kegiatan berakhir adalah pembimbingan dan pendampingan dilakukan melalui aplikasi Whattsap sebagai upaya pencegahan penularan covid-19 dengan meminimalisir kontak langsung.

Berdasarkan hasil kegiatan pengabdian yang telah dilakukan, maka saran yang dapat dikemukakan adalah berikut :

1. Untuk desa mitra memperbanyak konten atau isi website desa agar lebih menarik minat masyarakat berkunjung di laman website desa masing-masing mitra. Konten itu dapat berupa informasi terbaru mengenai inovasi budidaya tanaman, inovasi pasca panen hasil pertanian dan lain sebagainya.

2. Agar website desa mitra selalu melakukan perbaharuan konten setiap 2 minggu sekali. Update konten ini sangat perlu terkait dengan harapan masyarakat desa mitra menjadi pengunjung utama di laman website.

\section{DAFTAR PUSTAKA}

Achmad Sofiyudin, Rino Ardhian Nugroho. 2017. Implementasi Cyber Village dalam Mewujudkan Masyarakat Melek Teknologi Informasi dan Komunikasi Berbasis Internet di Daerah Pegunungan (Studi Kasus di Desa Campurejo, Kecamatan Tretep, Kabupaten Temanggung, Jawa Tengah). Jurnal Wacana Publik Vol 1 No 3, $2017 \mathrm{hlm} \mathrm{1-15.}$

Akbar, D. M., \& Aidha, Z. (2020). Perilaku Penerapan Gizi Seimbang Masyarakat Kota Binjai pada Masa Pandemi Covid-19 Tahun 2020. Menara Medika, 3(1).

Badri, M. (2016). Pembangunan pedesaan berbasis teknologi informasi dan komunikasi (studi pada gerakan desa membangun). Jurnal Dakwah Risalah, 27(2), 62-73 
Badri, Muhamad. 2016. Pembangunan Pedesaan Berbasis Teknologi Informasi dan Komunikasi (Studi Pada Gerakan Desa Membangun). Jurnal RISALAH, Vol. 27, No. 2, Desember 2016

Hita, I. P. A. D., Ariestika, E., Yacs, B. T. P. W. B., \& Pranata, D. (2020). Hubungan Status Gizi Terhadap Tingkat Aktivitas Fisik PMI Selama Masa Karantina Covid-19. Jurnal MensSana, 5(2), 151-161.

Pujilestari, Y. (2020). Dampak Positif Pembelajaran Online Dalam Sistem Pendidikan Indonesia Pasca Pandemi Covid-19. 'ADALAH, 4(1).

Tahir, A. (2012). Faktor-Faktor yang Mempengaruhi Implementasi Kebijakan Transparasi Penyelenggaraan Pemerintah Di Kota Gorontalo. Jurnal Akuntansi , XVI (3), 413426.

Utomo, P. P. (2013). Website Sebagai Pemenuhan Hak Politik Warga dalam Penyelenggaraan Pemerintah . Journal Mandatory, 10 (2), 59- 88.

Wahyono, S. B. (2011). Optimalisasi Program Desa Informasi Melalui Penguatan Kelembagaan. Jurnal Penelitian IPTEK-KOM, 13 (2), 30-41. 